\title{
Isolation and Characterization of Bacterial Pathogen Causing Soft Rot Disease of Potato Tubers
}

\author{
G. Biswal* and N.K. Dhal \\ Department of Plant Pathology, College of Agriculture OUAT, Bhubaneswar-3, India \\ *Corresponding author
}

\begin{tabular}{|l|}
\hline Ke y w or d s \\
Bacterial pathogen, \\
$\begin{array}{l}\text { Soft rot disease, } \\
\text { Potato tubers }\end{array}$ \\
\hline Article Info \\
\hline $\begin{array}{l}\text { Accepted: } \\
\text { 20 June } 2018 \\
\text { Available Online: } \\
\text { 10 July } 2018\end{array}$ \\
\hline
\end{tabular}

\section{Keywords}

Bacterial pathogen Soft rot disease, ato tuber

Accepted:

20 June 2018

Available

\section{A B S T R A C T}

The rotting of potato tubers is usually noticed from the time of planting till harvesting also in country stores as well as in cold stores. The proper isolation, pathogenicity testing and necessary characterization studies are very much essential for identification of actual causal organism which is very necessary for development of effective management strategy. In this context systematic studies were conducted in Department of Plant Pathology, College of Agriculture, Orissa University of Agriculture and Technology for isolation and characterization of bacterial pathogens causing soft rot of potato tubers which were collected from experimental plots of potato Research Project, Central Farm, OUAT, Bhubaneswar. From the rotted tissues the bacteria was isolated aseptically and pathogenicity was proved. Microscopic studies revealed the isolate was gram negative rod, non-capsulated with peritrichous flagella. Colonies on Nutrient Sucrose Agar medium were raised, convex, shining, white fluidal and slimy while grown on endo agar they found to be circular with initially pink coloured but later turning to deep red. The colonies on Tetrazolium Chloride medium were cream coloured. On Crystal Violet Pectate medium the bacterial masses produced deep cup shaped cavities on the petriplates. Biochemically, the response of isolates to ONPG, orinthrine and lysine was studied. Response for deamination, nitrate reduction, $\mathrm{H} 2 \mathrm{~S}$ production, citrate reduction recorded. Methyl red test was found to be positive while indole, melonate and esculin tests as negative. The isolate could ferment carbohydrates such as adonitol, rhamanose, trehalose, glucose, lactose while xylose, cellobiose, meliobiose, saccarose, raffinose not fermented. Furthermore, the isolates could express the presence of oxidase, not hydrolysed gelatine and starch. From all these studies it was confirmed that the causal organism was Pectobacterium carotovorum.

\section{Introduction}

The rotting of potato tubers is usually noticed from the time of planting till harvesting also in country stores as well as in cold stores. The rotten tubers may be of brown rot, soft rot, mixed brown rot and soft rot and other types. The proper isolation, pathogenicity testing and necessary characterization studies are very much essential for identification of actual causal organism which is very necessary for development of effective management strategy. In this context systematic methods were followed in Department of Plant Pathology, College of Agriculture, Orissa University of Agriculture and Technology for 
isolation and characterization of bacterial pathogens causing soft rot of potato tubers which had already been followed in Japan, Mauritius, Iran and Bangladesh (Rodney et al., 2010; Harita et al., 2010; Suga et al., 2013; Ravari et al., 2011; Rahman et al., 2012).

\section{Materials and Methods}

Potato tubers showing soft rot symptoms were collected from experimental plots of Potato Research Project O.U.A.T. in the year 2012. Tubers were washed with sterilized water, air dried and then surface sterilized with $70 \%$ ethyl alcohol. Each tuber was examined by cutting into two halves with the help of a flame sterilized knife. From the rotted tissues the bacteria was isolated aseptically and pathogenicity was proved in healthy tubers which developed symptoms similar to field infection.

\section{Pathogenicity test}

The test bacterial isolate were subjected to pathogenicity test to study their virulence and subsequently exposed to a series of biochemical tests for identification of bacterial isolates. Ten numbers of apparently healthy tubers were collected for each bacterial isolate. The tubers were washed thoroughly with distilled water followed by surface disinfection with $70 \%$ ethyl alcohol. A small deep bore was made up to the centre of each potato tuber with the help of a $5 \mathrm{~mm}$ size cork borer. Five such centrally hollow tubers were used for each bacterial isolate and five tubers were kept as control. $0.5 \mathrm{ml}$ of bacterial suspension (about $10^{8} \mathrm{cfu} / \mathrm{ml}$ ) was aseptically transferred into each of the bore well and the excised piece of the tuber was replaced to close its mouth of the well. Each inoculated tuber was kept in separate polythene packet and incubated at $27 \pm 1^{0} \mathrm{C}$ for 7 days. A set of five tubers inoculated with sterilized water served as control. Observations on type and extend of rotting were recorded after the period of incubation. The most virulent strains were selected for further studies.

\section{Morphological characterization of bacterial isolates}

\section{Gram staining for cell wall determinations}

For the purpose of Gram staining of bacteria, a thin smear of the bacterial suspension from a 24 hour old bacterial growth was made on a clean glass slide and air dried. The bacteria was heat fixed by running the under surface of slide over a flame of a burner for two to three times. Care was taken not to overheat bacterial smear and allowed to cool to normal temperature. The smear was then flooded with Hucker's Ammonium oxalate crystal violet solution for one minutes, followed by gently washing in running tap water until clean water flowed from the slide. Excess water was drain out. The smear was then flooded with Gram's modified Lugo's Iodine solution for 1 minute followed by washing and drying as described earlier. Then the smear was held in a inclined position and the decolourizer solution $(95 \%$ ethyl alcohol) was added drop by drop and was allowed to flow over the smear for about 06 seconds. Immediately, the slide was washed in running water. Finally, the smear was counter stained with safranie solution for 30seconds followed by immediate washing the slide in running water and blot dried. The smear was examined under a microscope using oil-immersion lens. Also, the shape and size of the bacterial cells were recorded.

\section{b) Studies on flagellar attachment}

Tannic acid and ammonical silver nitrate solutions were used for flagella staining. A faintly cloudy bacterial suspension was made by carefully transferring $1.0 \mathrm{ml}$ of sterile distilled water to the tuft of 24 hour slant. The bacteria was allowed to migrate into the water without any mechanical agitation to form a 
faintly cloud suspension. A loop full of distilled water placed at the centre of clean slide, A loop full of bacterial suspension was placed on the slide by just touching the distilled water and was allowed to air dry. The bacterial film thus prepared was flooded with tannic acid solution which was allowed to stand 5 to 6 minutes and then rinsed with distilled water.

Ammoniated silver nitrate solution was added over the smear for few seconds. Finally the slide was washed in running water and air dried. The smear was then examined under a microscope using oil immersion lens. The bacteria and flagella were stained brown and light brown respectively on a light to golden back ground.

\section{Cultural character of bacterial isolate}

\section{Growth on nutrient sucrose agar medium}

Studies on colony morphology of each test bacterial isolate were done separately by growing them on NSA plates following streak plate method. A loop of 24-48 hour old bacterial culture was taken aseptically with the help of inoculating needle and continuous streaks were drawn on well dried surface of NSA plates. The plates were incubated at $27 \pm 1^{0} \mathrm{C}$ in a BOD incubator for 24-48 hours. Observations on the shape, margin, elevation and colour of the bacterial colony were recorded.

\section{Bio-chemical character of bacterial isolates}

\section{Pectiolytic ability test}

Bacteria have been characterized on the basis of their ability to degrade pectin in food. Firstly, crystal violet pectate medium was prepared, sterilized and transferred into sterilized petridishes as described earlier. After solidification, the bacterial isolate was stab inoculated at four points on each plate and incubated for 48 hours. Observations on development of cavities on CVP medium were recorded. Formation of deep cup shaped cavities indicated $P$. carotovorum.

\section{Starch hydrolysis test}

Bacteria have been characterized on the basis of their ability to utilize complex insoluble organic food in the same manner as that of higher animals by secreting enzymes into the surrounding medium. Firstly, nutrient agar medium containing $1 \%$ soluble starch was prepared and sterilized.

The starch enriched medium was transferred into sterilized petridishes. After solidification, each bacterial isolate was inoculated separately by drawing 2-3 streaks on the medium surface and incubated at $27 \pm 1^{\circ} \mathrm{C}$ for 24 hours. Each petriplate with bacterial growth was flooded with Iodine solution. Formation of clear zone around the bacterial growth indicated positive reaction to hydrolysis of starch.

\section{Gelatine liquifaction test}

Bacteria have been differentiated on the basis of their pectiolytic potentialities such as the ability to liquefy gelatine. 5 to $7 \mathrm{ml}$ of nutrient gelatine medium after preparation was transferred into each tube sterilized and cooled. The tubes were kept vertically. Two tubes were simultaneously inoculated with bacterial species.

Two uninoculated tubes served as control. All were incubated at $27 \pm 1^{\circ} \mathrm{C}$.. Observations from $2^{\text {nd }}$ to $7^{\text {th }}$ day of incubation were taken. For the purpose, the tubes were placed at $4^{\circ} \mathrm{C}$ for 30 minutes after each specific growth period. Immediately after taking out from the low temperature condition, each tube was held parallel to the surface and gently tapped 3-4 times. Flowing of medium from the stub indicated positive reaction. The medium 
which flowed down after the $2^{\text {nd }}$ day of incubation recorded as fast liquification, $3^{\text {rd }}$ and $4^{\text {th }}$ day after incubation recorded as moderate liquification ability and no flowing of medium within $5-7^{\text {th }}$ day of inoculation indicated slow reaction. Each tube was compared with uninoculated control where the medium did not flow down even after tapping for 3-4times indicating negative result.

\section{Oxidase test}

Small quantity of 24 hours bacterial growth of each test bacterium was picked up with the help of platinum loop of an inoculation needle and was placed on commercially available oxidase discs (Hi-Media). Development of purple colour within 10 seconds was rated as oxidase positive. Colouration developing between 10-60 seconds rated as delayed positive and where no colour developed even after 60 seconds was rated as oxidase negative.

\section{e) Other biochemical tests}

Biochemical tests like citrate utilization, lysine decarboxylation, ornithine decarboxylation, urease detection, phenylalanine deamination, $\mathrm{H}_{2} \mathrm{~S}$ production, nitrate reduction, Voges Proskaur (VP), Berrits, Methyl red, Indole, Malonate and Esculin tests were done by using 'Hi Media' test kits.

\section{Carbohydrate utilization test}

The test bacterial isolates were characterized by the ability of the test bacterial species to utilize specific carbohydrates. Twelve carbohydrates such as; glucose, lactose, arabinose, adonitol, sorbitol, xylose, rhamnose, cellobiose, mellbiose, saccharose, raffinose, trehalose and esculin were tested using 'Hi Media Test Kit'. Separate test kits were used for each test bacterial isolate

\section{Results and Discussion}

Microscopic studies revealed that the isolate was gram negative rod, non-capsulated with peritrichous flagella. Colonies on Nutrient Sucrose Agar medium were raised ,convex, shining, white fluidal and slimy. Colonies on endo agar were found to be circular with initially pink coloured but later turning to deep red.

The colonies on Tetrazolium Chloride Medium were cream coloured. On Crystal Violet Pectate medium the bacterial masses produced deep cup shaped cavities on the petriplates (Table 1).

Biochemically, the isolates showed negative response to ONPG, failed to decarboxylase orinthrine and lysine.

The presence of urease was not observed. Deamination, nitrate reduction, $\mathrm{H}_{2} \mathrm{~S}$ production, citrate reduction could not be expressed. Methyl red test was found to be positive while indole, melonate and esculin tests as negative (Table 2). The isolate could ferment carbohydrates such as adonitol, rhamanose, trehalose, glucose, lactose while xylose, cellobiose, meliobiose, saccarose, raffinose not fermented (Table 3 ).

Furthermore, the isolates could express the presence of oxidase, not hydrolysed gelatine and starch. From all these studies it was confirmed that the causal organism was Pectobacterium carotovorum. BagheeRavleari et al., (2011) worked on biochemical characterization of Pectobacterium sp in Iran. Rahman et al., (2012) in Bangladesh while working on characterization and identification of soft rot bacterial pathogens in Bangladeshi potatoes also followed pathogenicity, Gram reaction test, nitrate reduction test, negative response to gelatine liquification, acetoin and indole test. 
Table.1 Morphological characters of bacterial isolate

\begin{tabular}{|r|l|c|}
\hline Sl.No & \multicolumn{1}{|c|}{ Morphological character } & Test bacterial isolate \\
\hline $\mathbf{1}$ & Gram staining & Gram negative \\
\hline $\mathbf{2}$ & Shape & Rod \\
\hline $\mathbf{3}$ & Flagella staining & Peritrichous flagella \\
\hline $\mathbf{4}$ & Capsule staining & No \\
\hline $\mathbf{5}$ & Colony characters & Fluidal, white colour \\
\hline $\mathbf{6}$ & Endo agar test & Red colonies \\
\hline $\mathbf{7}$ & Growth on crystal violet pectate medium & Cup shaped activities \\
\hline $\mathbf{8}$ & Size & $0.5-0.8$ X 1.0-1.5lu \\
\hline
\end{tabular}

Table.2 Bio-chemical test showing colour change due to reaction with of test bacterium

\begin{tabular}{|c|c|c|c|c|c|}
\hline $\begin{array}{l}\text { Sl. } \\
\text { No }\end{array}$ & $\begin{array}{l}\text { Biochemical } \\
\text { Tests }\end{array}$ & $\begin{array}{l}\text { Reagents to be } \\
\text { added after } \\
\text { incubation }\end{array}$ & Principle & $\begin{array}{l}\text { Original } \\
\text { colour }\end{array}$ & $\begin{array}{c}\text { Change of } \\
\text { colour indicating } \\
\text { reaction type } \\
\text {-ve }\end{array}$ \\
\hline 1 & ONPG & - & $\begin{array}{l}\text { Detects } \\
\text { B-galactosidase activity }\end{array}$ & $\begin{array}{l}\text { Orange } \\
\text { yellow }\end{array}$ & Yellow \\
\hline 2 & $\begin{array}{l}\text { Lysine } \\
\text { decarboxylase }\end{array}$ & - & $\begin{array}{l}\text { Detects lysine } \\
\text { decarboxylation }\end{array}$ & $\begin{array}{l}\text { Yellowish } \\
\text { green }\end{array}$ & Green \\
\hline 3 & $\begin{array}{l}\text { Orinthrine } \\
\text { decarboxylase }\end{array}$ & - & $\begin{array}{l}\text { Decarboxylation of amino } \\
\text { acid }\end{array}$ & Colourless & Cream \\
\hline 4 & Urease & - & $\begin{array}{l}\mathrm{NH}_{3} \text { changes the } \mathrm{pH} \text { of } \\
\text { the medium }\end{array}$ & Colourless & Yellow \\
\hline 5 & $\begin{array}{l}\text { Phenylalanine } \\
\text { deamination }\end{array}$ & $\begin{array}{l}\text { 2-3drops of TDA } \\
\text { reagent }\end{array}$ & $\begin{array}{l}\text { Detects phenyl alanine } \\
\text { deamination activity }\end{array}$ & $\begin{array}{l}\text { Orange } \\
\text { yellow }\end{array}$ & Yellow \\
\hline 6 & $\begin{array}{l}\text { Nitrate } \\
\text { reduction }\end{array}$ & $\begin{array}{l}\text { Sulphanilic Acid(1- } \\
\text { 2drops)+N,N, } \\
\text { Dimethyl } \\
\text {-1-Na phenyl amine } \\
\text { (1-2drops) }\end{array}$ & Detects nitrate reduction & Colourless & Yellow \\
\hline 7 & $\mathrm{H}_{2}$ SProduction & - & H2Sproduction & $\begin{array}{l}\text { Orange } \\
\text { yellow }\end{array}$ & Yellow \\
\hline 8 & $\begin{array}{l}\text { Citrate } \\
\text { utilization }\end{array}$ & - & $\begin{array}{l}\text { Detects to } \\
\text { Utilize citrates }\end{array}$ & $\begin{array}{l}\text { Yellowish } \\
\text { green }\end{array}$ & Green \\
\hline 9 & $\begin{array}{l}\text { Vogues } \\
\text { Proskauer }^{\mathrm{s}}\end{array}$ & $\begin{array}{l}\text { O”Meara } \\
\text { reagent,i.e. } \\
\text { Beritt reagent }(\mathrm{A})+ \\
\text { Beritt reagent(B) }\end{array}$ & $\begin{array}{l}\text { Detects acetoin } \\
\text { production }\end{array}$ & Colourless & $\operatorname{Red}(+v e)$ \\
\hline 10 & Methyl red & Methyl red reagent & Detects acid production & Colourless & Cream \\
\hline 11 & Indole & Kovac's reagent & Detects acid production & Colourless & Cream \\
\hline 12 & Melonate & - & $\begin{array}{l}\text { Sodium melonate as sole } \\
\text { carbon source }\end{array}$ & Light & Green \\
\hline 13 & Esculin & & Esculin hydrolysis & Cream & Amber \\
\hline
\end{tabular}


Table.3 Carbohydrate fermentation test showing colour change of the carbohydrates due to their fermentation by gram-negative rods

\begin{tabular}{|c|c|c|c|}
\hline \multirow[t]{2}{*}{$\begin{array}{l}\text { Sl. } \\
\text { No }\end{array}$} & \multirow[t]{2}{*}{ Carbohydrates } & \multirow[t]{2}{*}{$\begin{array}{l}\text { Original } \\
\text { colour }\end{array}$} & $\begin{array}{c}\text { Change in colour indicating } \\
\text { reaction type }\end{array}$ \\
\hline & & & - ve \\
\hline 1 & Arabinose & Red & Red \\
\hline 2 & Xylose & Red & Yellow(+ve) \\
\hline 3 & Adonitol & Red & Yellow (+ve) \\
\hline 4 & Rhamnose & Red & Yellow(+ve) \\
\hline 5 & Cellobiose & Red & Red(-ve) \\
\hline 6 & Melibose & Red & Red(-ve) \\
\hline 7 & Saccharose & Red & Red(-ve) \\
\hline 8 & Raffinose & Red & $\operatorname{Red}(-\mathrm{ve})$ \\
\hline 9 & Trehalose & Red & Red(-ve) \\
\hline 10 & Glucose & Red & Red(-ve) \\
\hline 11 & Lactose & Red & Red(-ve) \\
\hline
\end{tabular}

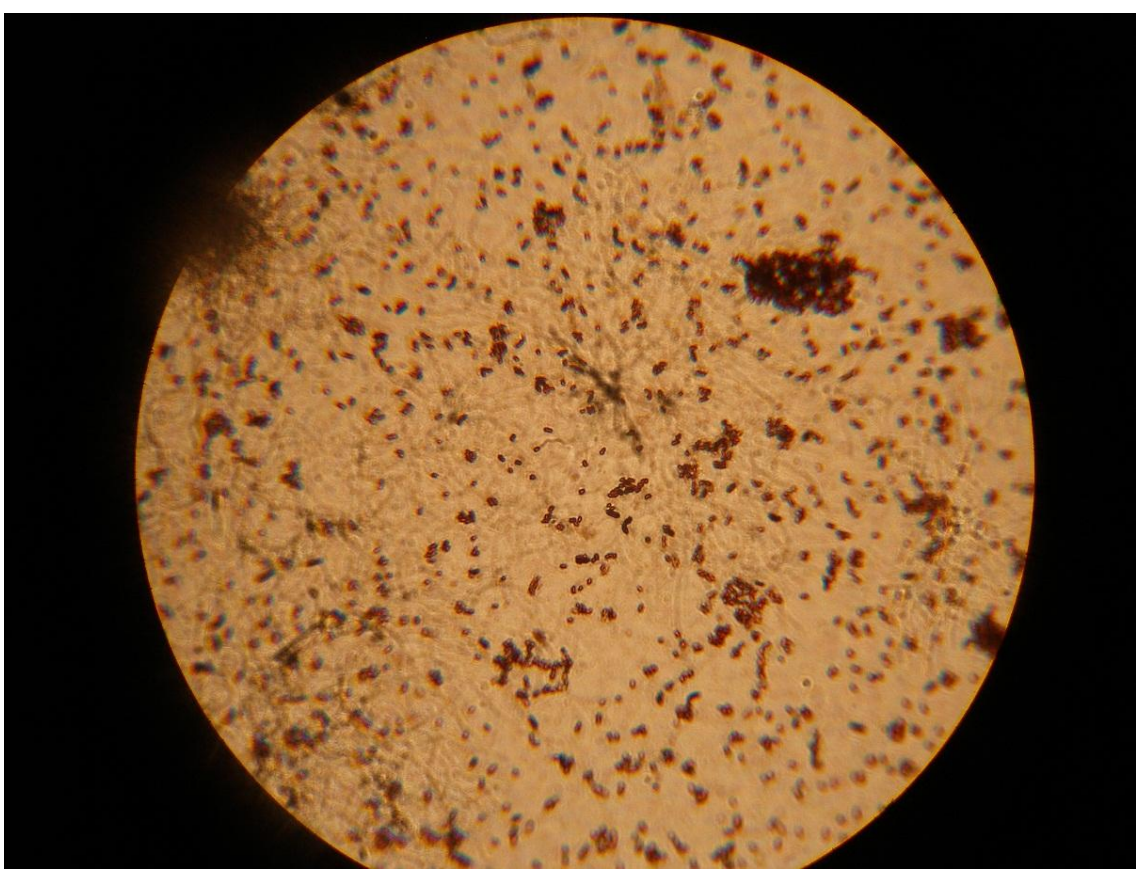

Plate.1 Photograh of Pectobacterium carotovorum at 1000X magnification 


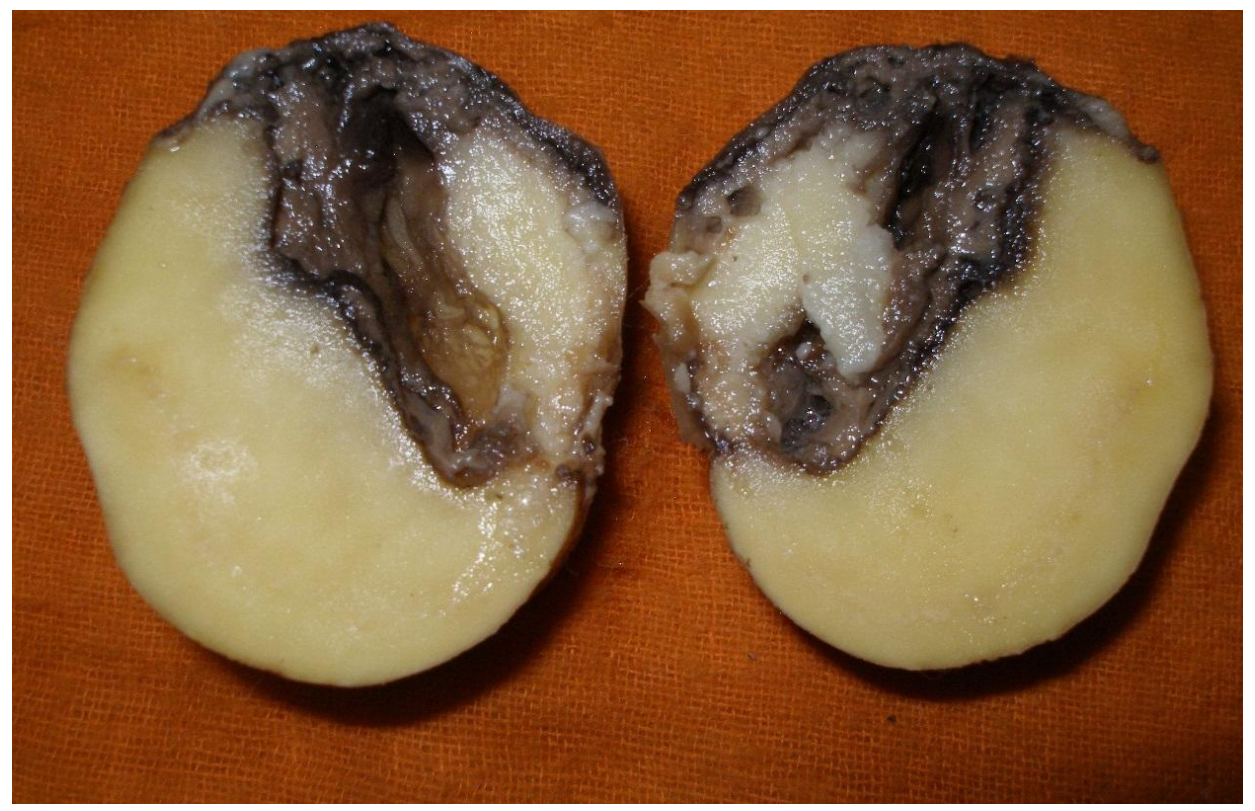

Plate.2 Photograph showing soft rotting of tuber within 15days of inoculation with P.carotovorum isolate
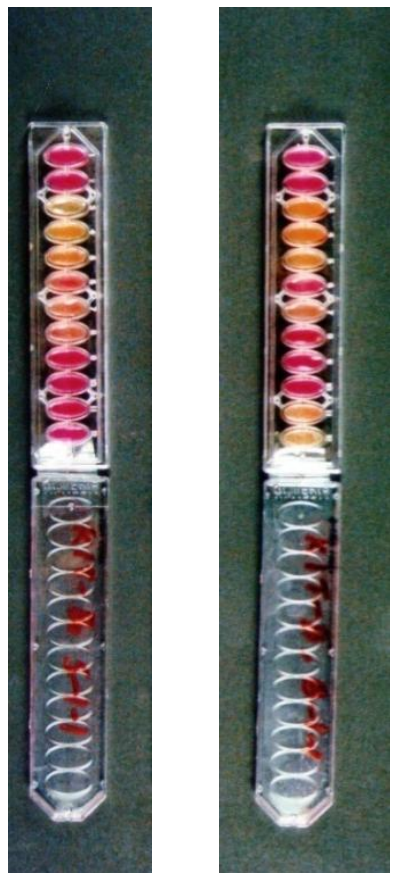

Plate.3 Biochemical test kits used for characterisation of bacterial isolates (A) Pectobacterium carotovorumand (B) control indicating different colour reactions 


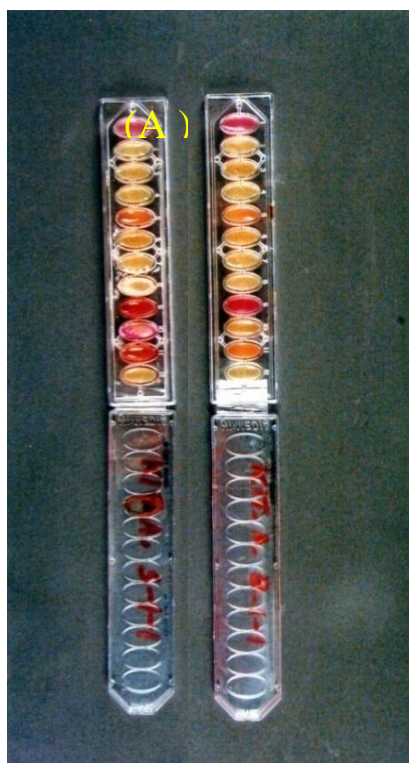

Plate.4 Test kits showing colour reaction in carbohydrate fermentation by (A) Pectobacterium carotovorum (B) Control

The common method of identification of the causal bacterial pathogen follows isolation, pathogenicity test followed by Gram staining, microscopic studies, growing them on selective medium ,a series of biochemical tests and carbohydrate tests

\section{References}

Baghee-Ravari S,Rahimiam H,Shoms Bakhash,Lopez-solanila E,AntanezLamas M, Rodriguez-Palenzuela P (2011) Characterisation of Pectobacterium species from Iran using biochemical and molecular methods. Eur.J.Plant Pathol 10:30503059.

Harita M,Suga Y,Ooshiro A,Tsuchiya K (2010) Analysis of genetic and biological characters of Japanese potato strains. J General Plant Patho 76(3):196-207.

Rahman MM,Equab Ali M,Khan A A.Hasim

U,Akanda A M,Hakim MA(2012)

Serological and molecular detection of late blight pathogen and disease development in potato. Inter $J$ Agriculture \&Biology.12 (2):161-170

Rodney KH, Ganoo MH, SAumtally ES.(2009).Molecular characterization and epidemiology of Ralstonia solanacearum Race3 biovar2 causing brown rot of potato in Mauritius. J.Phy.Pathol.157(7-8):503-512.

Suga Y, Horita M,Umekita M, Furya N, Tsuchiya K (2013).Pathogenic characters of Japanese potato strains of Ralstonia solanacearum. J. General Plant Pathol. 79(2):110-114

\section{How to cite this article:}

Biswal, G., and Dhal, N.K. 2018. Isolation and Characterization of Bacterial Pathogen Causing Soft Rot Disease of Potato Tubers. Int.J.Curr.Microbiol.App.Sci. 7(07): 2627-2634. doi: https://doi.org/10.20546/ijcmas.2018.707.308 